2018

\title{
A Test of the Institutionally Induced Equilibrium Hypothesis: On the Limited Fiscal Impact of Two Celebrity Governors
}

\author{
Roger D. Congleton \\ West Virginia University, roger.congleton@mail.wvu.edu \\ Yang Zhou \\ West Virginia University, ygzhou@mix.wvu.edu
}

Follow this and additional works at: https://researchrepository.wvu.edu/econ_working-papers

Part of the Public Economics Commons

\section{Digital Commons Citation}

Congleton, Roger D. and Zhou, Yang, "A Test of the Institutionally Induced Equilibrium Hypothesis: On the Limited Fiscal Impact of Two Celebrity Governors" (2018). Economics Faculty Working Papers Series. 8.

https://researchrepository.wvu.edu/econ_working-papers/8 


\section{WestVirginiaUniversity。}

Department of Economics

Working Paper Series

\section{A Test of the Institutionally Induced Equilibrium Hypothesis: On the Limited Fiscal Impact of Two Celebrity Governors}

Roger D. Congleton

Yang Zhou

Working Paper No. 18-02

This paper can be found at the College of Business and Economics Working Paper Series homepage: 


\title{
A Test of the Institutionally Induced Equilibrium Hypothesis: On the Limited Fiscal Impact of Two Celebrity Governors
}

\author{
Roger D. Congleton \\ Department of Economics \\ West Virginia University \\ Morgantown, WV 26506, USA \\ roger.congleton@mail.wvu.edu \\ Yang Zhou \\ Department of Economics \\ West Virginia University \\ Morgantown, WV 26506, USA \\ ygzhou@mix.wvu.edu
}

$1-11-18$

\begin{abstract}
We test for the stabilizing effects of political institutions on fiscal policies by examining the impact of two unlikely governors on their state's fiscal policies. Fiscal policies are joint products of executive and legislative decisions. These institutional factors tend to moderate the effect of changes in the chief executive, as does partisan competition for office. Jesse Ventura of Minnesota's and Arnold Schwarzenegger of California were unique-surprise-governors of their respective states. Although both governors were arguably less constrained by partisan loyalties than most others, the other institutional factors would still tend to limit their impact on public policy. Our evidence suggests that in spite of their unique path to office neither governor had a significant impact on their state’s expenditures or deficits.
\end{abstract}

Keywords: Government Experience, Outsidership, Governor, Fiscal Impact, Minnesota, Jesse Ventura, California, Arnold Schwarzenegger

JEL codes: H71, H72, H77 


\section{Introduction}

The first generation of rational-choice models of policy formation implied that the individuals holding high offices have little effect on public policies. In the most straightforward electoral models, candidates converge to very similar platforms and are assumed to implement their promises after the election is won (Downs 1957, Coughlin and Nitzan 1981). In the most straightforward interest group models, it is politically active groups rather than elected officials that matter. The persuasive campaigns of organized groups produce a stable vector of policies where the marginal influence of opposing groups equals one another (Tullock 1980, Becker 1983), and the balance of influence determines policy rather than the persons holding high office, who reflect those pressures rather than control them. Men and women who rise to influential positions in government are likely to be further constrained by promises and habits of thought that garnered support during previous stages in their careers. Insofar as median voter preferences over policies and the relative persuasiveness of interest groups are relatively stable, such models predict stable public policies that are largely beyond the influence of any single government official.

In the United States, the stabilizing effects of political competition are reinforced by the effects of divided governance. Presidents and governors have veto authority, but agenda control resides largely with multimember legislatures, where officeholders tend to have relatively long tenures because of advantages associated with incumbency. This division of authority as well as the internal organization of the legislature also tends to stabilize public policy (Buchanan and Tullock 1962, Shepsle and Weingast 1981). The senior staff of important government agencies also normally have long tenures in their agencies, and careerism together with bureaus' systems of formal and informal rewards tends to generate relatively stable bureau interests in policies and policy outcomes. These, in turn, further induce policy stability through their discretion over the implementation of legislation (Niskanen 1971, Congleton 1982, Weingast and Moran 1983).

Although elective office holders appear to have significant discretion over policy while in office, the first generation models imply that their policy choices are induced by a variety of institutionally generated incentives, promises made, and habits of thought and action developed prior to accession to high office. 
These classical models have been rebutted by what might be called second and third generation models of policy formation that imply officeholders have significant discretion over policies. There are, for example, analyses grounded in Arrow's (2012) impossibility theorem demonstrating that individual office holders can have major impacts on public policy if they have agenda control (McKelvey 1976). Several recent papers suggest that electoral competition is not as binding on candidate choices as the first models assumed. The extent of convergence in candidate platforms is limited by differences in candidate valence or ability (Groseclose 2001) in even very competitive elections. Besley and Coate (1997) suggest that candidate positions do not shift during elections but reflect their own honest (and inflexible) assessments of ideal policies, rather than those of the median voter or pivotal interest groups. Moreover, even with full convergence in party platforms, differences in the competence of those elected to high office can affect policy outcomes insofar as better prepared candidates are able to more effectively implement the same platform (Besley and Reynal-Querol 2011, Congleton and Zhang 2013).

There are also interest group models in which an elected or appointed official's assessments of the relative persuasiveness of interest group efforts directly affects public policy (Pelzman 1976, Grossman and Helpman 1994). If so, systematic changes in the types of individuals elected to high office or appointed to regulatory agencies will have effects on the policies and rules adopted. These effects will be systematic if the candidates elected or appointed to high office differ in their openness to particular lines of argument or are more or less beholding to interest group support. In these models, institutions bound the domain of policy choices, but sufficient discretion remains that the individuals holding high office have significant effects on the policies adopted and implemented.

This paper attempts to shed light on the relative merits of the "institutionally induced equilibrium" and the "officeholders matter" hypotheses by exploring the extent to which two very unlikely state governors had effects on their states' fiscal policies. The two governors focused on are men whose paths to governorship were unconventional and so less likely to be constrained by past promises to interest groups, partisanship, or electoral pressures than candidates whose rise to office followed a more conventional path. Neither had significant careers in politics before winning high office. 
Both men rose to high office through unorthodox, indeed unique, career paths and political circumstances. Jessie Ventura won as a third-party candidate with $36.9 \%$ of the vote against mainstream republican and democratic candidates. Arnold Schwarzenegger won a 2003 special recall election — the only one to do so in California history - in which there were many candidates. Schwarzenegger's rivals noted his inexperience and lack of preparation for governance. He nonetheless won office with relatively strong support (48\% of the votes). In neither case, could these governors be considered "groomed" for high office or known for their party loyalty, electoral experience, positions on public policy, or competence as policymakers. ${ }^{1}$

If particular officeholders matter in the United States, it should be most evident in cases in which unusual men rise to high office through unconventional-indeed surprising-elections.

\section{Models, Data, and Method}

We use three models of government fiscal policies and four regression discontinuity estimation strategies to determine whether these two unusual governors had unusual effects on their state's fiscal policies. We focus on three relatively lean models of state expenditures. A pure inertial model characterizes state expenditures as a simple autoregressive process generated by stable patterns of interest group influence, forward looking voters, and stable economic and political institutions.

$$
\mathrm{G}_{t}=\alpha+\beta_{1} G_{t-1}+\beta_{2} \text { Outsider }_{t}+\beta_{3} \text { Outsider }_{t} \times G_{t-1}+\mu_{t}
$$

$\mathrm{G}_{\mathrm{t}-1}$ is the lagged value of the fiscal variable of interest. Outsider $\mathrm{t}_{\mathrm{t}}$ is a binary variable that takes the value 1 if the state has an outsider governor in year $\mathrm{t}$ and the value 0 otherwise. Jesse Venture was Governor of Minnesota from January 4, 1999 to January 6, 2003, and Arnold Schwarzenegger was Governor of California from November 13, 2003 to January 3, 2011. The "Outsider Governor" binary variable for Minnesota has value 1 from 1999 to 2002 and is 0 otherwise. It has the value 1

\footnotetext{
${ }^{1}$ This is not to say that these men had absolutely no political experience. Ventura had been elected and served as the mayor of Brooklyn Park Minnesota, a city of 70,000 residents. Schwartznegger had served as chairman of California's Council on Physical Fitness.
} 
from 2004 to 2010 and is 0 otherwise for California. An outsider gubernatorial effect is a regime change in the autoregressive process, which requires $\beta_{2} \neq 0$ and/or $\beta_{3} \neq 0$.

The second model assumes that fiscal decisions reflect median voter demands. We characterize the reduced form median voter's demand as a linear function of his or her income in the previous period, $Y_{t-1}$. The lag reflects state budget cycles. ${ }^{2} \mathrm{We}$ assume that voters have similar tastes, which implies that median voter demand can be characterized as a function of median voter income and unmodeled random events during the year that affect turnout and voter expectations.

$$
\mathrm{G}_{t}=\alpha+\beta_{1} Y_{t-1}+\beta_{2} \text { Outsider }_{t}+\beta_{3} \text { Outsider }_{t} \times Y_{t-1}+\mu_{t}
$$

In the median voter model, a gubernatorial effect would systematically change the government's response to pivotal voter demands, which again requires $\beta_{2} \neq 0$ and/or $\beta_{3} \neq 0$.

Our third model of policy formation augments the median voter model with institutional variables that reflect the division of legislative authority and possible partisan effects. In cases in which full convergence in candidate platforms fails to take place, differences among candidate platforms are at least partially caused by advantages that parties realize by maintaining a stable "brand" or reputation for policy positions that differ from those of other party's. ${ }^{3}$ Party affiliation thus tends to affect bargaining that take place within state legislatures and between the governor and the legislature. In a median voter model, such partisan effects are affected by random events

${ }^{2}$ This model may seem a bit simplistic, but consider the following structural representation of median voter demand for government service $G$. Each voter maximizes a utility function $U=u(G, X)$ where $G$ is government service and $\mathrm{X}$ is their private good consumption. Because turnout rises with income, the median voter's income can be approximated with average income, $\mathrm{Y}^{\mathrm{A}}$. The median voter's private constraint is $\mathrm{X}=\left[1-\mathrm{t}\left(\mathrm{G}, \mathrm{N}, \mathrm{Y}^{\mathrm{A}}\right)\right] \mathrm{Y}^{\mathrm{A}}$ and her public constraint is $\mathrm{c}(\mathrm{G})=\mathrm{tNY} \mathrm{A}^{\mathrm{A}}$ where $\mathrm{N}$ is the adult state population, $\mathrm{c}(\mathrm{G})$ is the cost of public services, and $\mathrm{t}$ is the average tax rate. The tax rate will be a function of service level, population, average income. Maximizing utility generates a reduced form demand for government services of the form $\mathrm{Gj}^{*}=\gamma\left(\mathrm{Yj}^{\mathrm{A}}, \mathrm{Nj}\right)$ for state $\mathrm{j}$ with population $\mathrm{Nj}$, and will be approximately $\left(\mathrm{G} j^{*} / \mathrm{Nj}\right)=$ $\mathrm{g}\left(\mathrm{Yj}^{\mathrm{A}}\right)$ for per capital government expenditures. Treating $\mathrm{G}$ as a vector of services would not change the variable(s) in the reduced form.

${ }^{3}$ Such partisan effects are consistent with electoral competition models that include roles for political parties. In partisan models, parties create and maintain distinct policy agendas to retain their base of supporters (Duveger 1963, Alesina 1988, Grofman and Lijphart 2003). In such cases, one would expect to observe partisan effects but not office-holder effects, insofar as parties select their candidates for high office. 
that affect turnout, voter expectations, and the unobservable partisan dispositions of the persons running for office.

$$
\begin{gathered}
\mathrm{G}_{t}=\alpha+\beta_{1} Y_{t-1}+\beta_{2} \text { Outsider }_{t}+\beta_{3} \text { Outsider }_{t} \times Y_{t-1}+\beta_{4} \text { GovernorRepublican }_{t}+ \\
\beta_{5} \text { Senate }_{t}+\beta_{6}{\text { House } / \text { Assembly }_{t}+\mu_{t}}^{(3)}
\end{gathered}
$$

GovernorRepublican $_{\mathrm{t}}$ takes the value 1 if the governor is a republican and 0 otherwise. If the party in control of the senate is the same as the party of the governor, then Senate $t$ has the value 1 . It is 0 otherwise. The House/Assembly takes the value of 1 if the lower chamber is controlled by the same party as that of the state governor in year $t$, and it is 0 otherwise. A gubernatorial effect beyond that associated with party and divided governance would be indicated by a systematical change the government's response to pivotal voter demands, which again requires $\beta_{2} \neq 0$ and/or $\beta_{3} \neq 0$.

Data for the statistical analysis were collected from several sources. Median voter income is proxied with per capita real gross state products are from the Bureau of Economic Analysis (BEA). ${ }^{4}$ We use of average rather than median income because of the relatively higher turnout of high income voters. State level expenditure per capita and state level taxes per capita are from the Data Query System (DQS) of the Urban Institute. ${ }^{5}$ The governor and legislature information are collected from various online open sources. The websites include but are not limited to: the Minnesota State Legislature official website ${ }^{6}$, the California State Legislature official website 7 , California State Capitol Museum ${ }^{8}$, Ballotpedia- the online encyclopedia of American politics and elections $^{9}$, and related articles on Wikipedia. The time-period investigated is from 1987 to 2013. All nominal values are converted to 2012 constant dollars. Summary statistics are shown in Table 1.

\footnotetext{
${ }^{4}$ https://bea.gov/index.htm

${ }^{5}$ http://slfdqs.taxpolicycenter.org/pages.cfm

${ }^{6}$ https://www.leg.state.mn.us/

${ }^{7}$ http://www.legislature.ca.gov/

${ }^{8}$ http://www.capitolmuseum.ca.gov/

${ }^{9}$ https://ballotpedia.org/State_Legislatures
} 
Table 1: Descriptive Statistics (1987-2013, in 2012 Constant US dollars)

\begin{tabular}{|c|c|c|c|c|c|}
\hline Variable & $\begin{array}{c}\text { Number of } \\
\text { Observations }\end{array}$ & Mean & Std. Dev. & Minimum & Maximum \\
\hline MN RGDP Per Capita & 27 & 48255.51 & 6796.85 & 37549.79 & 56152.53 \\
\hline MN Expenditure Per Capita & 27 & 6102.59 & 1086.63 & 4422.00 & 7626.00 \\
\hline MN Deficit Per Capita & 27 & 2748.22 & 741.42 & 1584.00 & 4164.00 \\
\hline MN Outsider Governor Dummy & 27 & 0.15 & 0.36 & 0.00 & 1.00 \\
\hline MN Republican Governor Dummy & 27 & 0.59 & 0.50 & 0.00 & 1.00 \\
\hline MN Democrat Governor Dummy & 27 & 0.26 & 0.45 & 0.00 & 1.00 \\
\hline MN Senate Dummy & 27 & 0.19 & 0.40 & 0.00 & 1.00 \\
\hline MN House Dummy & 27 & 0.33 & 0.48 & 0.00 & 1.00 \\
\hline CA RGDP Per Capita & 27 & 49544.07 & 6647.96 & 40714.18 & 58858.56 \\
\hline CA Expenditure Per Capita & 27 & 6124.26 & 1113.76 & 4613.00 & 7761.00 \\
\hline CA Deficit Per Capita & 27 & 3173.89 & 865.02 & 1966.00 & 4498.00 \\
\hline CA Outsider Governor Dummy & 27 & 0.26 & 0.45 & 0.00 & 1.00 \\
\hline CA Republican Governor Dummy & 27 & 0.70 & 0.47 & 0.00 & 1.00 \\
\hline CA Democrat Governor Dummy & 27 & 0.30 & 0.47 & 0.00 & 1.00 \\
\hline CA Senate Dummy & 27 & 0.30 & 0.47 & 0.00 & 1.00 \\
\hline CA Assembly Dummy & 27 & 0.37 & 0.49 & 0.00 & 1.00 \\
\hline 10 States RGDP Per Capita & 270 & 44229.04 & 8400.29 & 26305.93 & 72495.71 \\
\hline 10 States Expenditure Per Capita & 270 & 5409.87 & 1163.09 & 3196.00 & 9132.00 \\
\hline 10 States Deficit Per Capita & 270 & 2890.76 & 855.86 & 1447.00 & 5430.00 \\
\hline $\begin{array}{c}10 \text { States Outsider Governor } \\
\text { Dummy }\end{array}$ & 270 & 0.04 & 0.20 & 0.00 & 1.00 \\
\hline $\begin{array}{c}10 \text { States Republican Governor } \\
\text { Dummy }\end{array}$ & 270 & 0.56 & 0.50 & 0.00 & 1.00 \\
\hline $\begin{array}{c}10 \text { States Democrat Governor } \\
\text { Dummy }\end{array}$ & 270 & 0.43 & 0.50 & 0.00 & 1.00 \\
\hline 10 States Senate Dummy & 270 & 0.51 & 0.50 & 0.00 & 1.00 \\
\hline $\begin{array}{c}10 \text { States House/Assembly } \\
\text { Dummy }\end{array}$ & 270 & 0.56 & 0.50 & 0.00 & 1.00 \\
\hline
\end{tabular}

\section{Single State Estimates of Fiscal Policies}

Table 2 reports estimates of the inertial, simple median voter, and institution-augmented median voter models of real per capita state government expenditures for Minnesota and California. Columns 1 and 4 report the inertial models for Minnesota and California, respectively. Columns 2 and 5 report the median voter model estimates, and Columns 3 and 6 report the institution- 
augmented median voter model estimates. All three models account for most of the variation in per capita expenditures in the two states. Only one of the six estimates supports the "governor matters" hypothesis. The median voter model for California exhibits governor specific effects that are significant at the $10 \%$ level. The other five estimates imply that there are no discontinuities in per capita state expenditures or in the responsiveness of government that can be attributed to the presence of an outsider governor, which is consistent with a strong form of the institutionally induced equilibrium hypothesis.

Table 2: Impact on Per Capita Government Expenditure

\begin{tabular}{|c|c|c|c|c|c|c|}
\hline \multirow[b]{2}{*}{ Variable } & \multicolumn{3}{|c|}{ Minnesota } & \multicolumn{3}{|c|}{ California } \\
\hline & $\begin{array}{c}\text { Auto- } \\
\text { regressive } \\
\text { Model }\end{array}$ & $\begin{array}{c}\text { Median } \\
\text { Voter Model }\end{array}$ & $\begin{array}{c}\text { Median Voter } \\
\text { Model with } \\
\text { Institutions }\end{array}$ & $\begin{array}{c}\text { Auto- } \\
\text { regressive } \\
\text { Model }\end{array}$ & $\begin{array}{c}\text { Median } \\
\text { Voter Model }\end{array}$ & $\begin{array}{c}\text { Median Voter } \\
\text { Model with } \\
\text { Institutions }\end{array}$ \\
\hline \multicolumn{7}{|l|}{ Expenditure $_{t}$} \\
\hline Constant & $\begin{array}{c}279.35 \\
(213.14)\end{array}$ & $\begin{array}{c}-1028.02 * * \\
(454.10)\end{array}$ & $\begin{array}{l}-750.21 \\
(679.05)\end{array}$ & $\begin{array}{c}127.63 \\
(350.34)\end{array}$ & $\begin{array}{c}-2422.68^{* * *} \\
(670.56)\end{array}$ & $\begin{array}{l}-1964.77 \\
(1439.47)\end{array}$ \\
\hline Outsider Governor ${ }_{t}$ & $\begin{array}{c}1165.30 \\
(1355.59)\end{array}$ & $\begin{array}{l}-2280.74 \\
(4845.58)\end{array}$ & $\begin{array}{l}-2558.54 \\
(4882.18)\end{array}$ & $\begin{array}{c}4122.86 \\
(4716.38)\end{array}$ & $\begin{array}{l}6740.09 * \\
(3715.30)\end{array}$ & $\begin{array}{c}6282.18 \\
(3909.01)\end{array}$ \\
\hline $\begin{array}{l}\text { Governor } \\
\text { Republican }_{\mathrm{t}}\end{array}$ & & & $\begin{array}{l}-180.57 \\
(260.36)\end{array}$ & & & $\begin{array}{l}\text { Omitted due } \\
\text { to collinearity } \\
\text { with the } \\
\text { Senate } \\
\text { Dummy }\end{array}$ \\
\hline Expenditure $_{\mathrm{t}-1}$ & $\begin{array}{c}0.97^{* * *} \\
(0.03)\end{array}$ & & & $\begin{array}{c}1.00^{* * *} \\
(0.06)\end{array}$ & & \\
\hline $\begin{array}{l}\text { Outsider Governor }{ }_{t} \times \\
\text { Expenditure }_{t-1}\end{array}$ & $\begin{array}{l}-0.15 \\
(0.22)\end{array}$ & & & $\begin{array}{l}-0.59 \\
(0.65)\end{array}$ & & \\
\hline Per Capita RGDP $\mathrm{t}_{\mathrm{t}-1}$ & & $\begin{array}{c}0.15^{* * *} \\
(0.01)\end{array}$ & $\begin{array}{c}0.15^{* * * *} \\
(0.01)\end{array}$ & & $\begin{array}{c}0.18^{* * *} \\
(0.01)\end{array}$ & $\begin{array}{c}0.16^{* * *} \\
(0.03)\end{array}$ \\
\hline $\begin{array}{l}\text { Outsider Governor }{ }_{t} \times \\
\text { RGDP }_{t-1}\end{array}$ & & $\begin{array}{c}0.05 \\
(0.10)\end{array}$ & $\begin{array}{c}0.05 \\
(0.10)\end{array}$ & & $\begin{array}{l}-0.13^{*} \\
(0.07)\end{array}$ & $\begin{array}{l}-0.11 \\
(0.07)\end{array}$ \\
\hline Senate $_{t}$ & & & $\begin{array}{l}-171.45 \\
(403.81)\end{array}$ & & & $\begin{array}{l}-136.28 \\
(436.29)\end{array}$ \\
\hline House/Assemblyt & & & $\begin{array}{l}-192.77 \\
(206.07)\end{array}$ & & & $\begin{array}{c}362.45 \\
(260.08)\end{array}$ \\
\hline $\mathrm{R}^{2}$ & 0.9732 & 0.9221 & 0.9324 & 0.9510 & 0.9182 & 0.9264 \\
\hline
\end{tabular}




\begin{tabular}{lccccc}
$\begin{array}{l}\text { Number of } \\
\text { Observations }\end{array}$ & 26 & 26 & 26 & 26 & 26 \\
$\begin{array}{l}\text { Durbin-Watson d- } \\
\text { statistic(k=4 or 7, } \\
\mathrm{n}=26)\end{array}$ & 2.1972 & 0.9859 & 1.3294 & 1.8157 & 0.8302 \\
\hline
\end{tabular}

$* * *, * *, *$ indicate significance at the $1 \%, 5 \%$, and $10 \%$ levels, respectively. Standard errors are in parentheses.

Table 3 provides estimates of the three models with real per capita state deficits as the dependent variable. ${ }^{10}$ Columns 1 and 4 report estimates of the inertial model for Minnesota and California. Columns 2 and 5 report the median voter model estimates, and Column 3 and 6 report the institution-augmented median voter model estimates. All three models account for most of the variation in per capita state deficits in Minnesota and California. None of the estimates support the "governors matter" hypothesis. There is no evidence of discontinuities in per capita state deficits or in the responsiveness of government to changes in average income when an "outsider" governor holds office.

Table 3: Impacts on Per Capita Government Deficit

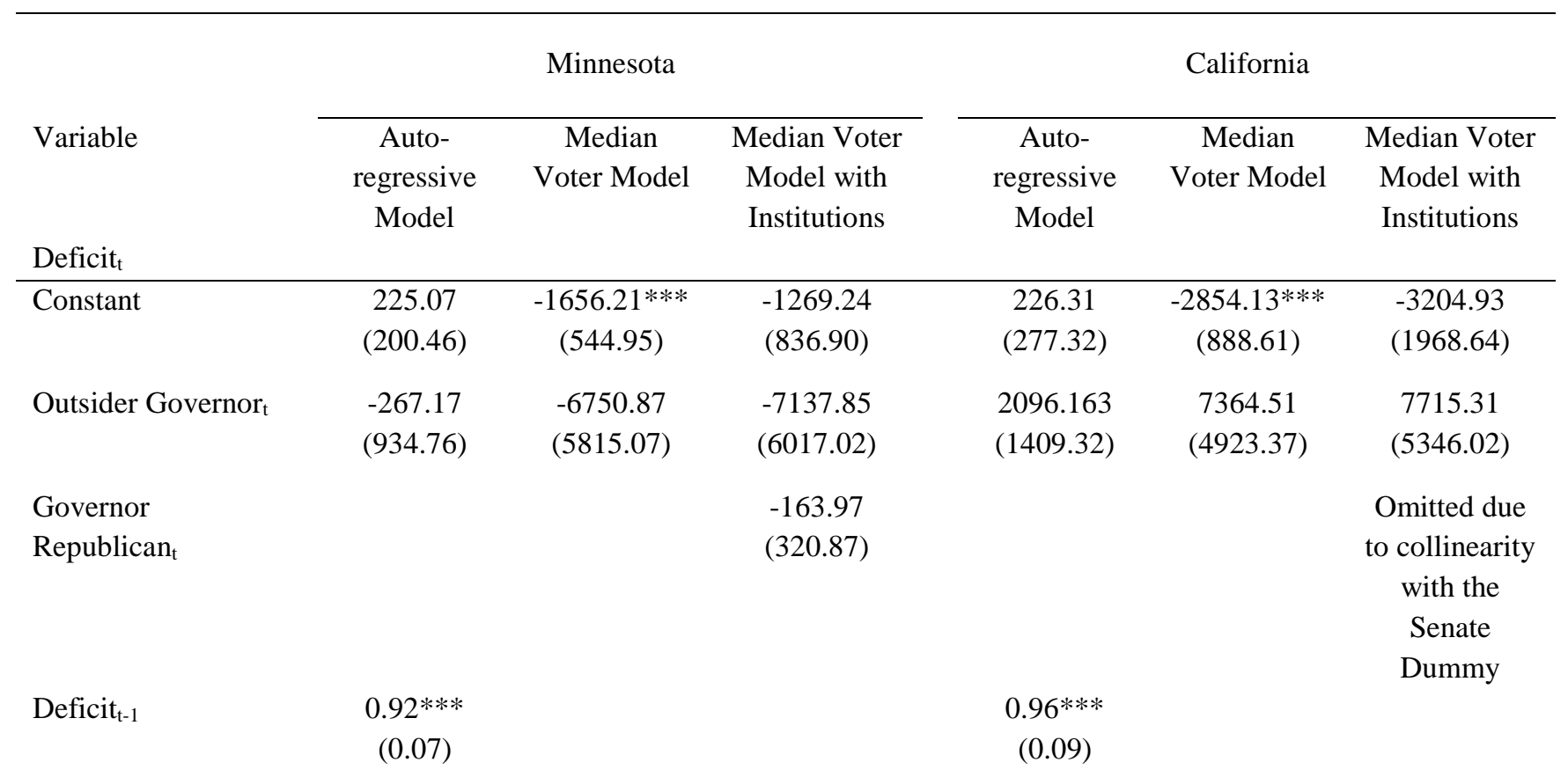

\footnotetext{
${ }^{10}$ Deficit per capita are calculated as the difference between real expenditures per capita and real taxes per capita.
} 


\begin{tabular}{|c|c|c|c|c|c|c|}
\hline $\begin{array}{l}\text { Outsider Governor } \mathrm{r}_{\mathrm{t}} \times \\
\text { Deficit }_{\mathrm{t}-1}\end{array}$ & $\begin{array}{c}0.24 \\
(0.37)\end{array}$ & & & $\begin{array}{l}-0.55 \\
(0.36)\end{array}$ & & \\
\hline Per Capita RGDP ${ }_{t-1}$ & & $\begin{array}{c}0.09^{* * *} \\
(0.01)\end{array}$ & $\begin{array}{c}0.09 * * * \\
(0.01)\end{array}$ & & $\begin{array}{c}0.12^{* * *} \\
(0.02)\end{array}$ & $\begin{array}{c}0.13^{* * *} \\
(0.05)\end{array}$ \\
\hline $\begin{array}{l}\text { Outsider Governor }{ }_{t} \\
\times_{\mathrm{RGDP}_{\mathrm{t}-1}}\end{array}$ & & $\begin{array}{c}0.13 \\
(0.12)\end{array}$ & $\begin{array}{c}0.14 \\
(0.12)\end{array}$ & & $\begin{array}{l}-0.13 \\
(0.09)\end{array}$ & $\begin{array}{l}-0.14 \\
(0.10)\end{array}$ \\
\hline Senate $_{t}$ & & & $\begin{array}{l}-291.16 \\
(497.68)\end{array}$ & & & $\begin{array}{l}-347.21 \\
(596.67)\end{array}$ \\
\hline House/Assembly & & & $\begin{array}{l}-112.67 \\
(253.97)\end{array}$ & & & $\begin{array}{c}333.06 \\
(355.69)\end{array}$ \\
\hline $\mathrm{R}^{2}$ & 0.8937 & 0.7647 & 0.7847 & 0.8770 & 0.7607 & 0.7709 \\
\hline $\begin{array}{l}\text { Number of } \\
\text { Observations }\end{array}$ & 26 & 26 & 26 & 26 & 26 & 26 \\
\hline $\begin{array}{l}\text { Durbin-Watson } d- \\
\text { statistic }(k=4 \text { or } 7 \text {, } \\
n=26)\end{array}$ & 1.5686 & 0.9388 & 1.0936 & 1.0901 & 0.8392 & 0.9184 \\
\hline
\end{tabular}

Significance Measures: ***, **, * indicate significance at the $1 \%, 5 \%$, and $10 \%$ levels, respectively. Standard errors are in parentheses.

\section{Regional Panel Estimates of Fiscal Policies}

State level estimates of the factors that contribute to public policy may be deemed superior to other cross sectional or pooled approaches because every state's political system includes unique features that affect trends and the sensitivity of policy choices to changes in political factors. However, a state by state approach limits the sample size, which can generate higher standard errors than feasible with other estimation strategies. It is possible that outsider governor effects exist, but that the small samples used in our single state estimates generate relatively large standard errors for the coefficient estimates and so reduce prospects for finding statistically significant effects. To explore this possibility, we assembled regional panels for California and Minnesota, consisting of one of those states and their four surrounding states. The states in these regional panels have similar histories, ethnicities, weather, and geography and thus are likely to have more or less similar political cultures.

The adjacent first ring states for Minnesota are Wisconsin, Iowa, South Dakota, and North Dakota. The adjacent first ring states for California are Arizona, Nevada, Oregon, and Washington. Within the upper midwestern panel, Jesse Ventura was the only independent candidate elected to 
the governorship. Within the western panel, Arnold Schwarzenegger was the only governor elected through a recall election. Thus, both governors may be regarded as unique for their respective panels. The tables reported below and in the appendix provides evidence that these panels are distinct from one another in that there are statistically significant differences in income elasticities and other parameter estimates across the two regions. (See Table 9 of the appendix.)

The panel estimation strategy is similar to that used for the single state estimates, but includes state fixed effects $\left(S_{i}\right)$ and year fixed effects $\left(T_{t}\right)$. The state fixed effects account for stable unmodeled differences among states and the year fixed effects account for common random macroeconomic and macropolitical shocks that might affect political deliberations within a state in a given year. The fixed-effects inertial model for the Minnesota and California panels is:

$$
\mathrm{G}_{i t}=\alpha+\beta_{1} G_{i t-1}+\beta_{2} \text { Governor }_{i t}+\beta_{3} \text { Governor }_{i t} \times G_{i t-1}+S_{i}+T_{t}+\mu_{i t}
$$

with $S_{i}$ being the state fixed effect and $T_{t}$ being a year fixed effect. The fixed effects median voter model is:

$$
\mathrm{G}_{i t}=\alpha+\beta_{1} Y_{i t-1}+\beta_{2} \text { Governor }_{i t}+\beta_{3} \text { Governor }_{i t} \times Y_{i t-1}+S_{i}+T_{t}+\mu_{i t}
$$

The fixed-effects median voter model with institutions is:

$$
\begin{aligned}
& \mathrm{G}_{i t}=\alpha+\beta_{1} Y_{i t-1}+\beta_{2} \text { Governor }_{i t}+\beta_{3} \text { Governor }_{i t} \times Y_{i t-1}+\beta_{4} \text { GovernorRepublican }_{i t}+
\end{aligned}
$$

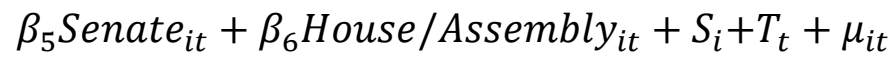

Table 4 reports panel estimates of the autoregressive, median voter, and augmented median voter models of real state per capita expenditure models. The constant term $\alpha$ is not reported in the table, because it is automatically included in the fixed effects terms thus omitted. The ordering of the models is the same as that in the previous tables. The results for the upper Midwest panel are very similar to the Minnesota estimates of Table 2 . There is no evidence of discontinuity induced by its outsider governor, and only very modest evidence of institutional and partisan effects. With respect to the western panel, we now find evidence of an outsider governor in the autoregressive model, but not the others. In the autoregressive model for the western panel, there is a quantum jump in California's average expenditures per capita, but a reduction in trend expenditures 
associated with that jump. This effect does not survive the shift to the median voter models, and so likely reflects differences in California politics that the fixed effects do not fully account for.

We also find evidence of significant partisan and institutional effects in the California panel. western states with Republican governors having systematically lower expenditures than those with democratic governors in the period of interest. Partisan and institutional effects are also implied by the significance of binary variables for state senate or house controlled by the same party as the governor. (The signs of those variables are, however, unrelated to the purposes of this study.) All three models account for most of the variation in state expenditures within their respective panels.

Table 4: Impact on Government Expenditure Per Capita (Panel Data with First Ring States)

\begin{tabular}{|c|c|c|c|c|c|c|}
\hline \multirow[b]{2}{*}{$\begin{array}{l}\text { Variable } \\
\text { Expenditure }_{t}\end{array}$} & \multicolumn{3}{|c|}{ Minnesota Panel } & \multicolumn{3}{|c|}{ California Panel } \\
\hline & $\begin{array}{c}\text { Auto-regressive } \\
\text { Model }\end{array}$ & $\begin{array}{c}\text { Median } \\
\text { Voter Model }\end{array}$ & $\begin{array}{c}\text { Median } \\
\text { Voter Model } \\
\text { with } \\
\text { Institutions }\end{array}$ & $\begin{array}{l}\text { Auto- } \\
\text { regressive } \\
\text { Model }\end{array}$ & $\begin{array}{c}\text { Median } \\
\text { Voter } \\
\text { Model }\end{array}$ & $\begin{array}{c}\text { Median } \\
\text { Voter Model } \\
\text { with } \\
\text { Institutions }\end{array}$ \\
\hline Outsider Governor ${ }_{t}$ & $\begin{array}{c}1094.88 \\
(1476.80)\end{array}$ & $\begin{array}{l}-1918.77 \\
(4057.57)\end{array}$ & $\begin{array}{l}-1968.56 \\
(4021.65)\end{array}$ & $\begin{array}{l}8220.03^{* *} \\
(3802.44)\end{array}$ & $\begin{array}{l}-1071.28 \\
(4949.75)\end{array}$ & $\begin{array}{c}-463.39 \\
(3847.879)\end{array}$ \\
\hline $\begin{array}{l}\text { Governor } \\
\text { Republican }_{\mathrm{t}}\end{array}$ & & & $\begin{array}{l}-81.58 \\
(66.28)\end{array}$ & & & $\begin{array}{c}-576.39 * * * \\
(84.94)\end{array}$ \\
\hline Expenditure $_{t-1}$ & $\begin{array}{c}0.90 * * * \\
(0.06)\end{array}$ & & & $\begin{array}{l}0.92 * * * \\
(0.04)\end{array}$ & & \\
\hline $\begin{array}{l}\text { Outsider Governor }{ }_{t} \\
\times \text { Expenditure }_{\mathrm{t}-1}\end{array}$ & $\begin{array}{l}-0.15 \\
(0.24)\end{array}$ & & & $\begin{array}{l}-1.16^{* *} \\
(0.53)\end{array}$ & & \\
\hline $\mathrm{RGDP}_{\mathrm{t}-1}$ & & $\begin{array}{c}0.07 * * * \\
(0.01)\end{array}$ & $\begin{array}{c}0.07 * * * \\
(0.01)\end{array}$ & & $\begin{array}{c}0.06^{* * *} \\
(0.01)\end{array}$ & $\begin{array}{c}0.04^{* * *} \\
(0.01)\end{array}$ \\
\hline $\begin{array}{l}\text { Outsider Governor } \\
\times \mathrm{RGDP}_{\mathrm{t}-1}\end{array}$ & & $\begin{array}{c}0.04 \\
(0.08)\end{array}$ & $\begin{array}{c}0.04 \\
(0.08)\end{array}$ & & $\begin{array}{c}0.03 \\
(0.09)\end{array}$ & $\begin{array}{c}0.02 \\
(0.07)\end{array}$ \\
\hline Senate $_{t}$ & & & $\begin{array}{c}-163.03^{* *} \\
(76.26)\end{array}$ & & & $\begin{array}{c}-165.19^{* *} \\
(71.58)\end{array}$ \\
\hline House/Assembly ${ }_{t}$ & & & $\begin{array}{c}71.47 \\
(65.42)\end{array}$ & & & $\begin{array}{l}127.53^{*} \\
(68.45)\end{array}$ \\
\hline State Fixed Effects & $\checkmark$ & $\checkmark$ & $\checkmark$ & $\checkmark$ & $\checkmark$ & $\checkmark$ \\
\hline
\end{tabular}




\begin{tabular}{lcccccc} 
Year Fixed Effects & $\checkmark$ & $\checkmark$ & $\checkmark$ & $\checkmark$ & $\checkmark$ & $\checkmark$ \\
\hline $\mathrm{R}^{2}$ & 0.6820 & 0.4540 & 0.4802 & 0.8299 & 0.2028 & 0.5347 \\
$\begin{array}{l}\text { Number of } \\
\text { Observations }\end{array}$ & 130 & 130 & 130 & 130 & 130 & 130 \\
\hline
\end{tabular}

$* * *, * *, *$ indicate significance at the $1 \%, 5 \%$, and $10 \%$ levels, respectively. Standard errors are in parentheses.

Table 5 reports panel estimates for real state per capita deficits (with state and year fixed effects). The ordering of the models is the same as that in the previous tables. The results for the Minnesota panel are similar to those of the Minnesota estimates of Table 3. There is no evidence of discontinuity induced by Minnesota's outsider governor in the upper midwestern panel, but there is evidence that institutions and party affect the magnitude of state deficits per capita. Deficits decline with republican governors and state senates of the same party as a state's governor.

With respect to the western panel, we again find evidence of discontinuities in the autoregressive model, but not in the median voter-based models. There is also evidence of partisan/institutional effects on state per capita deficits in the California panel. Western states with republican governors have systematically lower deficits than those with democratic governors in the period of interest. This effect is reinforced by the support of a state senate controlled by the same party, although reduced by a same party state house. The negative coefficient found for the effect of above average state income on deficits suggests that states in the upper Midwest plan expenditures based on typical economic conditions, rather than year-to-year fluctuations in income. Deficits thus fall during periods of relatively high income. The positive sign found for the Western panel suggests that deficit finance is a routine part of their state's fiscal planning. All three models account for most of the variation in state expenditures within their respective panels.

Table 5: Impact on Government Deficit Per Capita (Panel Data with First Ring States)

\begin{tabular}{|c|c|c|c|c|c|c|}
\hline & \multicolumn{3}{|c|}{ Minnesota Panel } & \multicolumn{3}{|c|}{ California Panel } \\
\hline Variable & $\begin{array}{l}\text { Auto- } \\
\text { regressive } \\
\text { Model }\end{array}$ & $\begin{array}{c}\text { Median } \\
\text { Voter Model }\end{array}$ & $\begin{array}{l}\text { Median Voter } \\
\text { Model with } \\
\text { Institutions }\end{array}$ & $\begin{array}{l}\text { Auto- } \\
\text { regressive } \\
\text { Model }\end{array}$ & $\begin{array}{c}\text { Median } \\
\text { Voter Model }\end{array}$ & $\begin{array}{l}\text { Median Voter } \\
\text { Model with } \\
\text { Institutions }\end{array}$ \\
\hline
\end{tabular}




\begin{tabular}{|c|c|c|c|c|c|c|}
\hline Outsider Governor $_{\mathrm{t}}$ & $\begin{array}{c}61.77 \\
(1006.36)\end{array}$ & $\begin{array}{l}-4457.76 \\
(4465.92)\end{array}$ & $\begin{array}{l}-4556.82 \\
(4242.98)\end{array}$ & $\begin{array}{l}1677.39 * \\
(925.64)\end{array}$ & $\begin{array}{c}862.41 \\
(4323.30)\end{array}$ & $\begin{array}{c}1264.46 \\
(3670.97)\end{array}$ \\
\hline $\begin{array}{l}\text { Governor } \\
\text { Republican }_{\mathrm{t}}\end{array}$ & & & $\begin{array}{l}-233.96 * * * \\
\quad(69.93)\end{array}$ & & & $\begin{array}{c}-379.23 * * * \\
(81.04)\end{array}$ \\
\hline Deficit $_{t-1}$ & $\begin{array}{c}0.91 * * * \\
(0.07)\end{array}$ & & & $\begin{array}{c}0.87^{* * * *} \\
(0.05)\end{array}$ & & \\
\hline $\begin{array}{l}\text { Outsider Governor }{ }_{t} \times \\
\text { Deficit }_{t-1}\end{array}$ & $\begin{array}{c}0.02 \\
(0.40)\end{array}$ & & & $\begin{array}{c}-0.46^{* *} \\
(0.23)\end{array}$ & & \\
\hline $\mathrm{RGDP}_{\mathrm{t}-1}$ & & $\begin{array}{c}-0.10^{* * *} \\
(0.01)\end{array}$ & $\begin{array}{c}-0.10^{* * *} \\
(0.01)\end{array}$ & & $\begin{array}{c}0.04 * * * \\
(0.01)\end{array}$ & $\begin{array}{c}0.03^{* * *} \\
(0.01)\end{array}$ \\
\hline $\begin{array}{l}\text { Outsider Governor }{ }_{\mathrm{t}} \times \\
\text { RGDP }_{\mathrm{t}-1}\end{array}$ & & $\begin{array}{c}0.09 \\
(0.09)\end{array}$ & $\begin{array}{c}0.09 \\
(0.09)\end{array}$ & & $\begin{array}{l}-0.01 \\
(0.08)\end{array}$ & $\begin{array}{l}-0.02 \\
(0.06)\end{array}$ \\
\hline Senate $_{t}$ & & & $\begin{array}{c}-202.81^{* *} \\
(80.46)\end{array}$ & & & $\begin{array}{c}-167.44^{* *} \\
(68.29)\end{array}$ \\
\hline House/Assembly & & & $\begin{array}{c}166.96^{* *} \\
(69.02)\end{array}$ & & & $\begin{array}{c}154.33^{* *} \\
(65.31)\end{array}$ \\
\hline State Fixed Effects & $\checkmark$ & $\checkmark$ & $\checkmark$ & $\checkmark$ & $\checkmark$ & $\checkmark$ \\
\hline Year Fixed Effects & $\checkmark$ & $\checkmark$ & $\checkmark$ & $\checkmark$ & $\checkmark$ & $\checkmark$ \\
\hline $\mathrm{R}^{2}$ & 0.6204 & 0.5848 & 0.6368 & 0.7509 & 0.1367 & 0.3989 \\
\hline $\begin{array}{l}\text { Number of } \\
\text { Observations }\end{array}$ & 130 & 130 & 130 & 130 & 130 & 130 \\
\hline
\end{tabular}

\section{Panel Estimates of Difference in Difference using Synthetic Controls}

We next explore whether the evidence found in the single state and panel estimates is robust to other estimation strategies. We next apply two difference in difference approaches, using different implementations of the synthetic control methodology (Abadie, Diamond, and Hainmueller 2015). In the first series of estimates we use panel averages as a synthetic controlwhich is to say, we create a hypothetical average panel state that can be used as the panel norm, or as a control to isolate the treatment effect generated by an unusual governor. We estimate differences between state i's expenditures in year $\mathrm{t}$ and the panel average for that year. We focus on the institution-augmented median voter model. An outsider governor effect will generate larger 
deviations from the panel norm than can be accounted for by income, partisanship, and institutional effects. We use differences between the average real per capita state gross product in the panel and actual state per capita gross product as the income explanatory variable.

Table 6 summarizes the results for the two variables of interest for each panel. Again, the models account for most of the variation in state per capita expenditures and deficits. Again, there is no evidence of discontinuities generated by "outsider" governors in the upper mid-West panel. However, we find some evidence of an outsider effect for the California panel, one that suggests a very large increase in per capita expenditures and per capita deficits, although the coefficient is significant at only the $10 \%$ level. Given the other results, we believe that this result is spurious and may reflect problems with pooling states in the Western panel. (California exhibits significantly higher income elasticity in voter demands for government services than other states in the panel.)

Table 6: Impact on Government Expenditures and Deficits Per Capita (Difference in Difference re Panel Averages, Pooled Data from First Ring States)

\begin{tabular}{|c|c|c|c|c|}
\hline \multirow[b]{2}{*}{ Variable } & \multicolumn{2}{|c|}{ Minnesota Panel } & \multicolumn{2}{|c|}{ California Panel } \\
\hline & $\begin{array}{c}\text { Median } \\
\text { Voter } \\
\text { Per Capita } \\
\text { Expenditure } \\
\text { Average } \\
\text { Difference }\end{array}$ & $\begin{array}{c}\text { Median } \\
\text { Voter } \\
\text { Per Capita } \\
\text { Deficit } \\
\text { Average } \\
\text { Difference }\end{array}$ & $\begin{array}{c}\text { Median } \\
\text { Voter } \\
\text { Per Capita } \\
\text { Expenditure } \\
\text { Average } \\
\text { Difference } \\
\end{array}$ & $\begin{array}{c}\text { Median } \\
\text { Voter } \\
\text { Per Capita } \\
\text { Deficit } \\
\text { Average } \\
\text { Difference } \\
\end{array}$ \\
\hline Outsider Governor $r_{t}$ & $\begin{array}{c}-501.62 \\
(2447.99)\end{array}$ & $\begin{array}{l}-1924.95 \\
(2588.00)\end{array}$ & $\begin{array}{l}4775.65 * \\
(2478.76)\end{array}$ & $\begin{array}{l}4049.64 * \\
(2367.56)\end{array}$ \\
\hline $\begin{array}{l}\text { Governor } \\
\text { Republican }_{\mathrm{t}}\end{array}$ & $\begin{array}{l}-81.63 \\
(66.35)\end{array}$ & $\begin{array}{c}-234.01^{* * *} \\
(70.14)\end{array}$ & $\begin{array}{c}-586.78^{* * *} \\
(84.06)\end{array}$ & $\begin{array}{c}-388.58^{* * *} \\
(80.29)\end{array}$ \\
\hline $\begin{array}{l}\text { RGDP Average } \\
\text { Difference }_{t-1}\end{array}$ & $\begin{array}{c}0.07 * * * \\
(0.01)\end{array}$ & $\begin{array}{c}-0.10^{* * *} \\
(0.01)\end{array}$ & $\begin{array}{c}0.04 * * * \\
(0.01)\end{array}$ & $\begin{array}{c}0.03^{* * *} \\
(0.01)\end{array}$ \\
\hline $\begin{array}{l}\text { Outsider Governor } \mathrm{r}_{\mathrm{t}} \\
\text { RGDP Average }\end{array}$ & $\begin{array}{c}0.06 \\
(0.31)\end{array}$ & $\begin{array}{c}0.27 \\
(0.33)\end{array}$ & $\begin{array}{l}-0.84 \\
(0.52)\end{array}$ & $\begin{array}{l}-0.76 \\
(0.49)\end{array}$ \\
\hline Senate $_{t}$ & $\begin{array}{c}-162.97^{* *} \\
(76.34)\end{array}$ & $\begin{array}{l}-202.75^{* *} \\
(80.71)\end{array}$ & $\begin{array}{c}-163.94 * * \\
(70.56)\end{array}$ & $\begin{array}{c}-164.56^{* *} \\
(67.40)\end{array}$ \\
\hline House/Assembly & $\begin{array}{c}71.44 \\
(65.49)\end{array}$ & $\begin{array}{c}166.93^{* *} \\
(69.23)\end{array}$ & $\begin{array}{l}114.69 * \\
(67.93)\end{array}$ & $\begin{array}{c}143.76^{* *} \\
(64.88)\end{array}$ \\
\hline State Fixed Effects & $\checkmark$ & $\checkmark$ & $\checkmark$ & $\checkmark$ \\
\hline
\end{tabular}




\begin{tabular}{lcccc} 
Year Fixed Effects & $\checkmark$ & $\checkmark$ & $\checkmark$ & $\checkmark$ \\
\hline $\mathrm{R}^{2}$ & 0.4791 & 0.6346 & 0.5470 & 0.4134 \\
$\begin{array}{l}\text { Number of } \\
\text { Observations }\end{array}$ & 130 & 130 & 130 & 130
\end{tabular}

Significance Measures: ***, **, * indicate significance at the 1\%, 5\%, and 10\% levels, respectively. Standard errors are in parentheses.

Our last series of estimates uses a more sophisticated method for creating a hypothetical reference state or synthetic control. We create a synthetic control for each state by estimating annual values of each state's real per capital expenditures and deficits as a function of the other states in their panel's fiscal outcomes (real per capita expenditures, real per capita deficits). Each state thus has its own synthetic control, which is, in effect, a BLUE weighted average of the fiscal outcomes in other states in the panels. The weights vary by state and panel and are reported in Table 8 of the appendix. The estimated values provide synthetic state governments for each state in each panel that can be used as the hypothetical norm or reference for the states and panels of interest.

We again focus on the institution-augmented median voter model. Differences between each state's actual and its predicted per capita expenditures and per capita deficits are used as the relevant dependent variables. In effect, the differences are now state-level residuals with respect to their synthetic control. We use a similar difference between the synthetic control's state per capita income and actual income in the state of interest as the income variable. The estimates look for unexplained effects on the residuals associated with the tenures of the two outsider governors relative to that which would have occurred without them, as in conventional time-series applications of the synthetic control methodology. Outsider-governor effects on fiscal outcomes in their respective states should be highlighted by this approach. This estimation strategy is applied to the upper Mid-Western and Western Panels and to the states of California and Minnesota alone.

Table 7 reports the results for each panel and the two states of interest. The synthetic controls for each panel account for most of the predicable path of real per capita state expenditures and deficits; and thus, the explanatory power of the models fall significantly. We find second-order effects for changes for average income shocks on real state per capita expenditures, but not deficits, 
which suggests that state expenditures are normally adjusted to account for past tax revenue shocks (possibly generated by unexpected changes in average income in the previous year). We also find second-order effects from same party assemblies with respect to expenditures in the upper midWest, but not in the Western panel. There is, however, no evidence of a systematic effect of outsider governors on real per capita expenditures or deficits.

Table 7: Impact on Government Expenditures and Deficits Per Capita (Difference in Difference re Modified Synthetic Control, Panel Data with First Ring States)

\begin{tabular}{|c|c|c|c|c|c|c|c|c|}
\hline \multirow[b]{2}{*}{ Variable } & \multicolumn{2}{|c|}{ Minnesota } & \multicolumn{2}{|c|}{ California } & \multicolumn{2}{|c|}{ Minnesota Panel } & \multicolumn{2}{|c|}{ California Panel } \\
\hline & $\begin{array}{l}\text { Per Capita } \\
\text { Expenditure } \\
\text { Weighted } \\
\text { Difference }\end{array}$ & $\begin{array}{c}\text { Per Capita } \\
\text { Deficit } \\
\text { Weighted } \\
\text { Difference }\end{array}$ & $\begin{array}{l}\text { Per Capita } \\
\text { Expenditure } \\
\text { Weighted } \\
\text { Difference }\end{array}$ & $\begin{array}{c}\text { Per Capita } \\
\text { Deficit } \\
\text { Weighted } \\
\text { Difference }\end{array}$ & $\begin{array}{l}\text { Per Capita } \\
\text { Expenditure } \\
\text { Weighted } \\
\text { Difference }\end{array}$ & $\begin{array}{c}\text { Per Capita } \\
\text { Deficit } \\
\text { Weighted } \\
\text { Difference }\end{array}$ & $\begin{array}{l}\text { Per Capita } \\
\text { Expenditure } \\
\text { Weighted } \\
\text { Difference }\end{array}$ & $\begin{array}{l}\text { Per Capita } \\
\text { Deficit } \\
\text { Weighted } \\
\text { Difference }\end{array}$ \\
\hline Constant & $\begin{array}{c}-188.19 * \\
(89.98)\end{array}$ & $\begin{array}{c}-139.92 \\
(106.26)\end{array}$ & $\begin{array}{c}184.26 \\
(210.28)\end{array}$ & $\begin{array}{c}14.09 \\
(214.97)\end{array}$ & & & & \\
\hline $\begin{array}{l}\text { Outsider } \\
\text { Governor }_{t}\end{array}$ & $\begin{array}{l}\text { 139.91* } \\
\text { (111.66) }\end{array}$ & $\begin{array}{c}100.48 \\
(131.87)\end{array}$ & $\begin{array}{c}-28.99 \\
(147.54)\end{array}$ & $\begin{array}{c}56.11 \\
(150.84)\end{array}$ & $\begin{array}{c}5.99 \\
(108.32)\end{array}$ & $\begin{array}{c}-200.19 \\
(194.26)\end{array}$ & $\begin{array}{l}-132.19 \\
(169.36)\end{array}$ & $\begin{array}{c}9.55 \\
(155.36)\end{array}$ \\
\hline $\begin{array}{l}\text { Governor } \\
\text { Republican }_{t}\end{array}$ & $\begin{array}{l}172.25 * \\
(96.58)\end{array}$ & $\begin{array}{c}183.05 \\
(114.05)\end{array}$ & $\begin{array}{l}-326.36 * \\
(188.59)\end{array}$ & $\begin{array}{c}-115.22 \\
(192.80)\end{array}$ & $\begin{array}{l}-14.38 \\
(46.46)\end{array}$ & $\begin{array}{l}-17.63 \\
(83.32)\end{array}$ & $\begin{array}{c}-123.74 * \\
(69.39)\end{array}$ & $\begin{array}{c}-103.60 \\
(63.65)\end{array}$ \\
\hline $\begin{array}{l}\text { RGDP } \\
\text { Weighted } \\
\text { Difference }_{\text {t-1 }}\end{array}$ & $\begin{array}{l}-0.02 \\
(0.04)\end{array}$ & $\begin{array}{l}-0.03 \\
(0.05)\end{array}$ & $\begin{array}{c}0.08 * * \\
(0.03)\end{array}$ & $\begin{array}{l}0.06 * \\
(0.03)\end{array}$ & $\begin{array}{c}0.02^{* * *} \\
(0.01)\end{array}$ & $\begin{array}{l}-0.005 \\
(0.014)\end{array}$ & $\begin{array}{l}0.03 * \\
(0.01)\end{array}$ & $\begin{array}{c}0.01 \\
(0.01)\end{array}$ \\
\hline $\begin{array}{l}\text { Outsider } \\
\text { Governor }_{\mathrm{t}} \times \\
\text { RGDP } \\
\text { Weighted } \\
\text { Difference }_{\mathrm{t}-1} 1\end{array}$ & $\begin{array}{l}-0.11 \\
(0.10)\end{array}$ & $\begin{array}{l}-0.04 \\
(0.12)\end{array}$ & $\begin{array}{c}0.36 \\
(0.30)\end{array}$ & $\begin{array}{c}0.31 \\
(0.30)\end{array}$ & $\begin{array}{l}-0.14 \\
(0.14)\end{array}$ & $\begin{array}{l}-0.12 \\
(0.25)\end{array}$ & $\begin{array}{c}0.37 \\
(0.36)\end{array}$ & $\begin{array}{c}0.38 \\
(0.33)\end{array}$ \\
\hline Senate $_{t}$ & $\begin{array}{c}171.71 \\
(132.67)\end{array}$ & $\begin{array}{c}247.09 \\
(156.68)\end{array}$ & $\begin{array}{c}\text { Omitted } \\
\text { due to } \\
\text { collinearit } \\
\text { y }\end{array}$ & $\begin{array}{l}\text { Omitted } \\
\text { due to } \\
\text { collinear } \\
\text { ity }\end{array}$ & $\begin{array}{c}-35.32 \\
(53.42)\end{array}$ & $\begin{array}{c}50.75 \\
(95.81)\end{array}$ & $\begin{array}{c}0.53 \\
(56.92)\end{array}$ & $\begin{array}{c}4.36 \\
(52.22)\end{array}$ \\
\hline $\begin{array}{l}\text { House/Asse } \\
\text { mblyt }\end{array}$ & $\begin{array}{l}117.86 \\
(81.28)\end{array}$ & $\begin{array}{l}-70.87 \\
(95.99)\end{array}$ & $\begin{array}{c}36.08 \\
(202.10)\end{array}$ & $\begin{array}{c}58.35 \\
(206.61)\end{array}$ & $\begin{array}{c}94.99 * * \\
(45.73)\end{array}$ & $\begin{array}{l}-45.58 \\
(82.00)\end{array}$ & $\begin{array}{l}-19.13 \\
(57.25)\end{array}$ & $\begin{array}{c}-4.32 \\
(52.52)\end{array}$ \\
\hline $\begin{array}{l}\text { State Fixed } \\
\text { Effects }\end{array}$ & & & & & $\checkmark$ & $\checkmark$ & $\checkmark$ & $\checkmark$ \\
\hline $\begin{array}{l}\text { Year Fixed } \\
\text { Effects }\end{array}$ & & & & & $\checkmark$ & $\checkmark$ & $\checkmark$ & $\checkmark$ \\
\hline
\end{tabular}




\begin{tabular}{lcccccccc}
\hline $\mathrm{R}^{2}$ & 0.3525 & 0.1920 & 0.4270 & 0.2469 & 0.1384 & 0.0178 & 0.1047 & 0.0655 \\
$\begin{array}{l}\text { Number of } \\
\text { Observation }\end{array}$ & 26 & 26 & 26 & 26 & 130 & 130 & 130 & 130 \\
$\mathrm{~s}$ & & & & & & & & \\
\hline
\end{tabular}

Significance Measures: ${ }^{* * *}, * *, *$ indicate significance at the $1 \%, 5 \%$, and $10 \%$ levels, respectively. Standard errors are in parentheses.

\section{Conclusions}

Most of the statistical evidence developed in this paper supports the institutionally induced equilibria hypothesis. We find little evidence that unusual persons who rise to governorships through unorthodox career paths have unusual effects on state budgets or borrowing. If we assume that the results reflect a likelihood function across models and estimates, we can conclude the institutionally induced equilibria hypothesis is more likely to be correct than the governors matter hypothesis, at least for the states and time period explored. This is not to say that unusual governors had no unusual effects on the policies directly controlled by the governor, which are beyond the scope of this study, but it is to say that these unusual men did not have a unique impact on their state's overall fiscal policies, at least not ones that can be discerned through statistical methods. We do, however, find evidence that that the party affiliation of office holders matter. We also find significant partisan and institutional effects, as found in many other studies.

Of secondary importance for the purposes of this paper, but perhaps of greater importance for the literature on state and local finance as a whole, is that the parameter estimates differed significantly across states and panels. For example, we found significant partisan effects on deficits in the upper Midwest, but partisan effects on both expenditures and deficits for states near the West Coast. In both the panel and state estimates, the estimated effects of income on state expenditures differed by more than 2 standard deviation. Together these results suggest that the effects of partisan organizations, political institutions, and political culture differ significantly across regions. This in turn suggests that the use of pooled national data sets for these sorts of studies is likely to generate biased parameter estimates. Fixed state and time effects evidently do not adequately adjust for differences in governmental responsiveness to income and party, nor fully account for differences in political culture. 
The support provided by this study for the institutionally-induced-equilibria hypothesis is limited to the institutional setting explored. State governments in the United States tend to have more fiscal discretion than most other sub-national governments, but are subject to more procedural constraints than confronted in many national governments. The effects of individuals holding their nation's or region's most powerful office is, for example, likely to be far greater in dictatorships and also in parliamentary systems in which a prime minister or chancellor can unilaterally make broad policy decisions that directly affect government expenditures, taxes, and deficits. However, for the United States, our results suggest that men and women with unique paths to high office are unlikely to have effects on policy that differ significantly from those of more conventional members of their political parties.

\section{References}

Abadie, A., Diamond, A., \& Hainmueller, J. (2015). Comparative politics and the synthetic control method. American Journal of Political Science, 59(2), 495-510.

Alesina, A. (1988). Credibility and policy convergence in a two-party system with rational voters." American Economic Review 78: 796-806.

Arrow, K. J. (2012). Social choice and individual values (Vol. 12). Yale University Press.

Becker, G. (1983). A theory of competition among pressure groups for political influence. The Quarterly Journal of Economics, 98(3), 371-400.

Besley, T., Montalvo, J., \& M. Reynal-Querol, (2011). Do educated leaders matter? Economic Journal 121: 205-27.

Besley, T. \& Coate, S. (1997). An economic model of representative democracy. Quarterly Journal of Economics 112: 85-114.

Buchanan, J. M., \& Tullock, G. (1962). The calculus of consent. Ann Arbor: University of Michigan Press.

Congleton, R. D. \& Zhang, J. J. (2013). Is it all about competence? The human capital of U.S. presidents and economic performance." Constitutional Political Economy 24: 108-24. 
Congleton, R. D. (1982). A model of asymmetric bureaucratic inertia and bias. Public Choice, 39(3), 421-425.

Cougnlin, P., \& Nitzan S. (1981). Electoral outcomes with probabilistic voting and Nash social welfare maxima. Journal of Public Economics 15: 113-21.

Downs, A. (1957). An economic theory of political action in a democracy. Journal of Political Economy, 65(2), 135-150.

Duverger, M. (1963). Political Parties: Their Organization and Activity in the Modern State. New York: Wiley.

Grofman, B. \& Lijphart, A. (2003). Electoral Laws and Their Political Consequences. New York: Algora Publishing.

Groseclose, T. (2001). A model of candidate location when one candidate has a valence advantage. American Journal of Political Science, 862-886.

Grossman, G., \& Helpman, E. (1994). Protection for sale. The American Economic Review, 84(4), 833-850.

McKelvey, R. D. (1976). Intransitivities in multidimensional voting models and some implications for agenda control. Journal of Economic Theory, 12(3), 472-482.

Niskanen, W. A. (1971). Bureaucracy and representative government. Transaction Publishers.

Peltzman, S. (1976). Toward a More General Theory of Regulation. The Journal of Law and Economics 19(2), 211-240.

Shepsle, K. A., \& Weingast, B. R. (1981). Structure-induced equilibrium and legislative choice. Public Choice, 37(3), 503-519.

Tullock, G. (1980). Efficient rent seeking, in Buchanan, J. M., Tollison, R. D. and Tullock, G. (Eds.) Toward a Theory of the Rent-Seeking Society. College Park TX: Texas A\&M Press, pp. 97-112; reprinted in Congleton, R. D., Hillman, A. L., and Konrad, K. A. (eds) (2008), Forty Years of Research on Rent Seeking, Heidelberg: Springer, pp. 105-120.

Weingast, B. R., \& Moran, M. J. (1983). Bureaucratic discretion or congressional control? Regulatory policymaking by the Federal Trade Commission. Journal of Political Economy, 91(5), 765800. 


\section{Appendix}

Table 8: OLS Weights for GDP Per Capita, Government Expenditure Per Capita and Deficit Per Capita When Constructing the "Synthetic Counterfactual” (First Ring States)

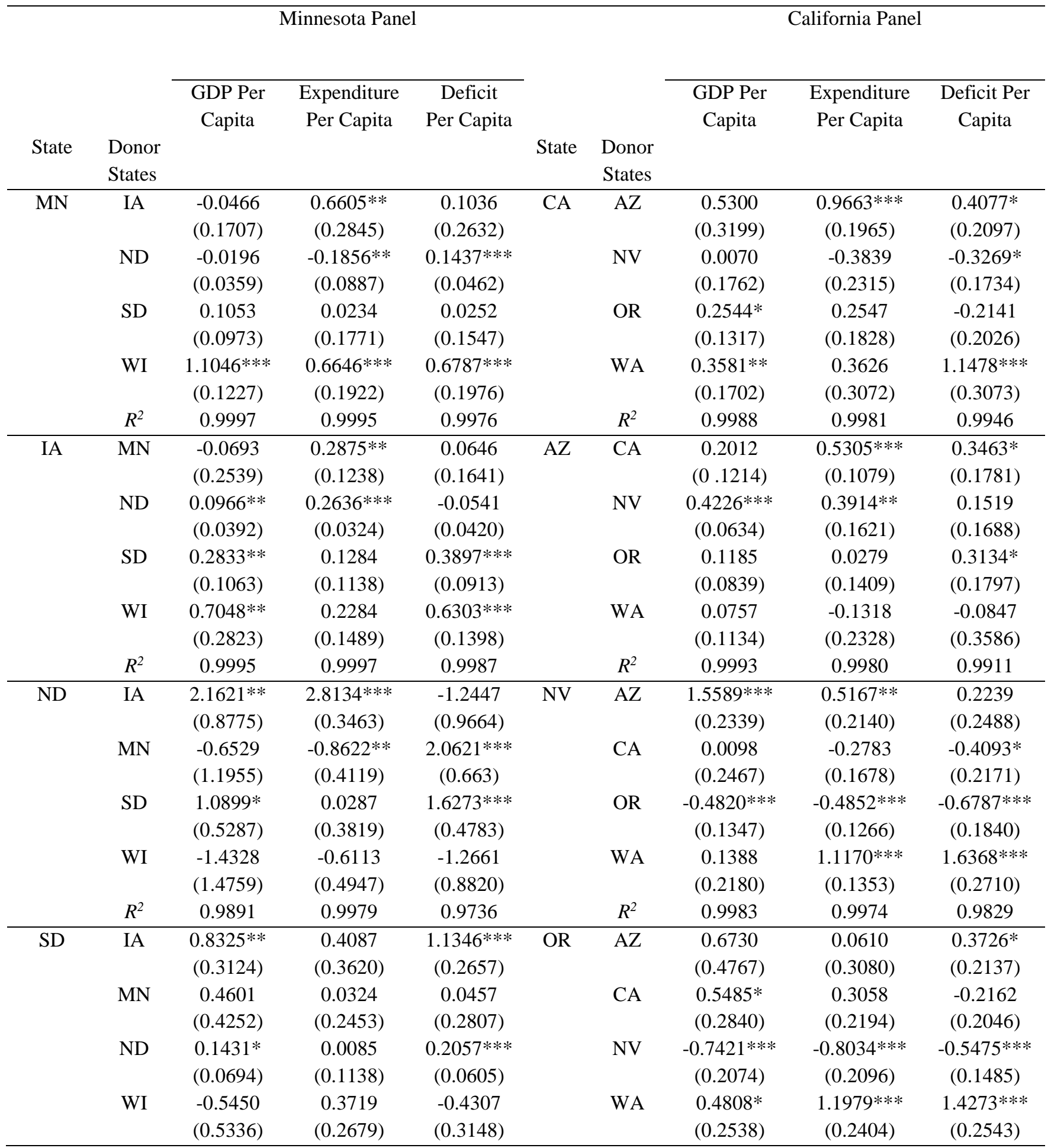




\begin{tabular}{|c|c|c|c|c|c|c|c|c|c|}
\hline & $R^{2}$ & 0.9984 & 0.9988 & 0.9959 & & $R^{2}$ & 0.9965 & 0.9974 & 0.9959 \\
\hline \multirow[t]{9}{*}{$\overline{\mathrm{WI}}$} & IA & $0.3025^{* *}$ & 0.4062 & $0.7445 * * *$ & \multirow[t]{9}{*}{ WA } & \multirow[t]{2}{*}{$\overline{A Z}$} & 0.2511 & -0.1042 & -0.0286 \\
\hline & & $(0.1212)$ & (0.2649) & $(0.1651)$ & & & $(0.3761)$ & $(0.1842)$ & $(0.1210)$ \\
\hline & MN & $0.7053^{* * *}$ & $0.5145 * * *$ & $0.4996 * * *$ & & \multirow[t]{2}{*}{ CA } & $0.4509 * *$ & 0.1575 & $0.3289 * * *$ \\
\hline & & $(0.0783)$ & (0.1488) & $(0.1454)$ & & & $(0.2143)$ & $(0.1334)$ & $(0.0881)$ \\
\hline & ND & -0.0275 & -0.1019 & -0.0649 & & \multirow[t]{2}{*}{ NV } & 0.1248 & $0.6692^{* * *}$ & $0.3747 * * *$ \\
\hline & & $(0.0283)$ & $(0.0824)$ & $(0.0452)$ & & & $(0.1960)$ & $(0.0811)$ & $(0.0620)$ \\
\hline & SD & -0.0796 & 0.2078 & -0.1747 & & \multirow[t]{2}{*}{ OR } & $0.2808 *$ & $0.4334 * * *$ & $0.4050^{* * *}$ \\
\hline & & (0.0779) & $(0.1497)$ & (0.1277) & & & $(0.1482)$ & $(0.0870)$ & $(0.0721)$ \\
\hline & $R^{2}$ & 0.9998 & 0.9996 & 0.9984 & & $R^{2}$ & 0.9986 & 0.9991 & 0.9985 \\
\hline $\begin{array}{c}\text { Number } \\
\text { of }\end{array}$ & & 27 & 27 & 27 & & & 27 & 27 & 27 \\
\hline $\begin{array}{c}\text { Observ- } \\
\text { ations }\end{array}$ & & & & & & & & & \\
\hline
\end{tabular}

Significance Measures: ${ }^{* * *},{ }^{* *}, *$ indicate significance at the $1 \%, 5 \%$, and $10 \%$ levels, respectively. Standard errors are in parentheses. 
Table 9: Pooled panel with Ventura and Schwarzenegger (10 states, levels and natural logs)

\begin{tabular}{|c|c|c|c|c|c|}
\hline \multicolumn{3}{|c|}{ Pooled Panel (level) } & \multicolumn{3}{|c|}{ Pooled Panel (natural log) } \\
\hline Variable & $\begin{array}{c}\text { Median Voter } \\
\text { Model } \\
\text { Per Capita } \\
\text { Expenditure } \\
\end{array}$ & $\begin{array}{l}\text { Median Voter } \\
\text { Model } \\
\text { Per Capita } \\
\text { Deficit } \\
\end{array}$ & $\begin{array}{c}\text { Variable } \\
\text { Ln } \mathrm{G}_{\mathrm{t}}\end{array}$ & $\begin{array}{c}\text { Median Voter } \\
\text { Model } \\
\text { Per Capita } \\
\text { Expenditure }\end{array}$ & $\begin{array}{l}\text { Median Voter } \\
\text { Model Per } \\
\text { Capita Deficit }\end{array}$ \\
\hline Outsider Governor ${ }_{\mathrm{t}}$ & $\begin{array}{c}-4362.45 * * * \\
(1476.45)\end{array}$ & $\begin{array}{c}-3461.11^{* *} \\
(1624.73)\end{array}$ & Outsider Governor ${ }_{t}$ & $\begin{array}{c}-7.352 * * * \\
(2.732)\end{array}$ & $\begin{array}{c}-12.250^{* *} \\
(6.154)\end{array}$ \\
\hline $\begin{array}{l}\text { Governor } \\
\text { Republican }_{\mathrm{t}}\end{array}$ & $\begin{array}{c}-323.59 * * * \\
(48.78)\end{array}$ & $\begin{array}{c}-398.14^{* * *} \\
(53.68)\end{array}$ & $\begin{array}{c}\text { Governor } \\
\text { Republican }_{\mathrm{t}}\end{array}$ & $\begin{array}{c}-0.064 * * * \\
(0.008)\end{array}$ & $\begin{array}{c}-0.148 * * * \\
(0.019)\end{array}$ \\
\hline $\mathrm{GDP}_{\mathrm{t}-1}$ & $\begin{array}{c}0.069 * * * \\
(0.006)\end{array}$ & $\begin{array}{c}-0.042^{* * *} \\
(0.007)\end{array}$ & Ln GDP ${ }_{t-1}$ & $\begin{array}{c}0.414^{* * *} \\
(0.049)\end{array}$ & $\begin{array}{c}-0.723 * * * \\
(0.110)\end{array}$ \\
\hline $\begin{array}{l}\text { Outsider Governor }{ }_{t} \times \\
\text { GDP }_{t-1}\end{array}$ & $\begin{array}{c}0.087 * * * \\
(0.027)\end{array}$ & $\begin{array}{c}0.068 * * \\
(0.030)\end{array}$ & $\begin{array}{l}\text { Outsider Governor } \\
\quad \times \text { Ln GDP } \text { GD-1 }_{t}\end{array}$ & $\begin{array}{c}0.679 * * * \\
(0.251)\end{array}$ & $\begin{array}{l}1.130 * * \\
(0.565)\end{array}$ \\
\hline Senate $_{t}$ & $\begin{array}{c}-186.01^{* * *} \\
(46.48)\end{array}$ & $\begin{array}{c}-143.74 * * * \\
(51.14)\end{array}$ & Senate $_{\mathrm{t}}$ & $\begin{array}{c}-0.038 * * * \\
(0.008)\end{array}$ & $\begin{array}{c}-0.060 * * * \\
(0.018)\end{array}$ \\
\hline House/Assembly & $\begin{array}{c}140.98 * * * \\
(44.85)\end{array}$ & $\begin{array}{c}200.94^{* * *} \\
(49.35)\end{array}$ & House/Assembly & $\begin{array}{c}0.020 * * \\
(0.008)\end{array}$ & $\begin{array}{c}0.064 * * * \\
(0.017)\end{array}$ \\
\hline Western State & $\begin{array}{l}\text { Omitted due to } \\
\text { collinearity }\end{array}$ & $\begin{array}{l}\text { Omitted due } \\
\text { to collinearity }\end{array}$ & Western State & $\begin{array}{l}\text { Omitted due to } \\
\text { collinearity }\end{array}$ & $\begin{array}{l}\text { Omitted due to } \\
\text { collinearity }\end{array}$ \\
\hline $\begin{array}{l}\text { Western State } \times \\
\text { GDP }_{\mathrm{t}-1}\end{array}$ & $\begin{array}{c}-0.021^{* * *} \\
(0.006)\end{array}$ & $\begin{array}{c}0.017 * * * \\
(0.006)\end{array}$ & $\begin{array}{l}\text { Western State } \times \text { Ln } \\
\text { GDP }_{\mathrm{t}-1}\end{array}$ & $\begin{array}{c}-0.123^{* * *} \\
(0.042)\end{array}$ & $\begin{array}{c}0.072 \\
(0.094)\end{array}$ \\
\hline State Fixed Effects & $\checkmark$ & $\checkmark$ & State Fixed Effects & $\checkmark$ & $\checkmark$ \\
\hline Year Fixed Effects & $\checkmark$ & $\checkmark$ & Year Fixed Effects & $\checkmark$ & $\checkmark$ \\
\hline $\mathrm{R}^{2}$ & 0.5059 & 0.3159 & & 0.4622 & 0.3296 \\
\hline $\begin{array}{l}\text { Number of } \\
\text { Observations }\end{array}$ & 260 & 260 & & 260 & 260 \\
\hline
\end{tabular}

Significance Measures: ***, **, * indicate significance at the 1\%, 5\%, and 10\% levels, respectively. Standard errors are in parentheses. 